\title{
Implementation of Gender Responsive Learning in Bhayangkari Kindergarten of Ruteng
}

\author{
ADRIANI TAMO INA TALU1 \& ELISABETH SARINASTITIN² \\ 1, 2Early Childhood Education of Teacher Education Study Program of Catholic Indonesian \\ Sint Paul University \\ Email: ${ }^{1}$ inatalu@gmail.com, ${ }^{2}$ elisabethsarinastitin@gmail.com
}

Article Received: 30 July 2020

Published Article: 01 June 2020

DOI: https://doi.org/10.29313/ga:jpaud.v4i1.4922

\begin{abstract}
The research objectives are to know the description of gender-responsive learning practiced by schools; Comparing whether what is practiced by schools is by gender-responsive learning indicators or not, and Knowing the gender-responsive learning model developed Bhayangkari Kindergarten. The research method used is qualitative descriptive research. The study results show. First, the learning process carried out at Bhayangkari Kindergarten has met the norms of gender equality and justice seen from the learning planning process, teaching and learning interactions, classroom management, and learning evaluation. Second, Bhayangkari Kindergarten has developed a learning process based on indicators of gender-responsive learning in early childhood by giving equal opportunities to women and men to gain access and active participation in learning, obtaining the same rights and obligations in the learning process, obtaining services that the same and obtain the same teaching materials. Third, to develop gender-responsive learning in Bhayangkari Kindergarten, the school pays attention to grouping children while playing and learning.
\end{abstract}

Keywords: Gender Responsive Learning; Kindergarten.

\begin{abstract}
Abstrak
Tujuan penelitian adalah mengetahui gambaran pembelajaran responsif gender yang dipraktikkan oleh sekolah; Membandingkan apakah yang dipraktikkan oleh sekolah sudah sesuai dengan indikator pembelajaran responsif gender atau belum; dan Mengetahui model pembelajaran responsif gender yang dikembangkan oleh TK Bhayangkari. Metode penelitian yang digunakan adalah penelitian deskriptif kualitatif. Hasil penelitian menunjukkan pertama, proses pembelajaran yang dilakukan di TK Bhayangkari telah memenuhi kaidah kesetaraan dan keadilan gender yang dilihat dari proses perencanaan pembelajaran, interaksi belajar mengajar, pengelolaan kelas dan evaluasi belajar. Kedua, TK Bhayangkari telah mengembangkan proses pembelajaran berdasarkan indikator pembelajaran responsif gender pada anak usia dini yaitu dengan memberi kesempatan yang sama kepada perempuan dan laki-laki memperoleh akses dan partisipasi aktif dalam pembelajaran, memperoleh hak dan kewajiban yang sama dalam proses pembelajaran, memperoleh layanan yang sama dan memperoleh bahan ajar yang sama.vKetiga, untuk mengembangkan pembelajaran responsif gender di TK Bhayangkari, pihak sekolah memerhatikan pengelompokkan anak saat bermain dan belajar.
\end{abstract}

Kata Kunci: Pembelajaran Responsif Gender; Taman Kanak-Kanak. 
Adriani Tamo Ina Talu. Elisabeth Sarinastitin/ Implementation of Gender Responsive Learning in Bhayangkari Kindergarten of Ruteng

\section{INTRODUCTION}

The issue of gender disparity at various levels of education still occurs. This is seen in a macro indicator of gender equality and justice called the Gender Development Index (GDI). In 2017, Indonesia ranked 84th out of 144 countries for gender equality. This means that there are still many problems related to gender rays. The problem of gender ray is also found in many educational institutions.

Paulo Freire (1999: 444), sees the importance of education as a source of virtue but on the other hand, has also become a great oppressor. Education, which is generally considered to have a general mission to educate the nation, actually turns out to play an active role in stunting students because they are unable to make them more humane or more humane. Freire's statement was confirmed by Suciati (the redesigned daily newspaper of August 9, 2006), which explained examples of informal oppression education found in textbooks, found in many pictures and sentence formulations that did not reflect gender equality. For example, a pilot's image is always male because the job as a pilot requires skills and strength that is only owned by men. Simultaneously, pictures of teachers who are teaching in class are always women because the teacher is always identified with the task of caring or educating.

This situation also occurs in early childhood learning. Toys and group arrangements for boys and girls are divided into boxes. Boys are given toy cars, pistols while girls are given toy dolls, markets, and the like. This urbanization continues to construct the child's identity, the attitude of children who tend to be patterned according to stereotypes based on the gender ray construct.

Faced with a gender ray situation, educational institutions should be forums for the formation and awareness of gender equality. Early childhood education institutions (kindergarten institutions) are very strategic levels of education and are the main determinants in forming necessary attitudes, knowledge, and skills. One of them is a forum for the formation and awareness of gender equality.

Gender-responsive learning will be a solution to overcome gender rays since early childhood.
Gender-responsive learning is a learning process that provides balanced attention to the unique needs of men and women. Gender-responsive learning requires educators to pay attention to various approaches to learning that meet the principles of gender equality and justice through learning planning, teaching-learning interactions, classroom management, and learning evaluation.

Indicators of gender-responsive learning include women and men getting equal access to active participation, obtaining the same rights and obligations in the same learning/teaching materials, and obtaining the same services.

Bhayangkari Kindergarten, as one of the early childhood education institutions, has implemented gender-responsive learning in services to early childhood. This inspired the writer to examine deeper what kind of implementation of gender-responsive learning is applied by the institution. Are they compatible with the learning approach and indicators of gender-responsive learning? Thus, this study aims to describe the implementation model of genderresponsive learning conducted by Bhayangkari Kindergarten of Ruteng.

Based on the description, the target of the outcome to be achieved is the teacher's description and understanding of the implementation of the gender responsive learning model in Bhayangkari Kindergarten.

\section{RESEARCH METHOD}

This type of research is a qualitative descriptive study. According to Sugiyono (2012: 9), qualitative research is a research method used to examine natural objects, where researchers as a key instrument. The results of the study are explained descriptively according to the data collected.

Stages of research related to the steps taken in collecting research data include the first, the preparation phase. This stage consists of several activities, namely arranging the instrument lines related to gender-responsive learning, preparing observation sheets and interview questions, and determining the days for observation. Second, the implementation phase. The activities carried out are observing learning in schools, conducting interviews 
Adriani Tamo Ina Talu. Elisabeth Sarinastitin/ Implementation of Gender Responsive Learning in Bhayangkari Kindergarten of Ruteng

with teachers and principals, and conducting documentation studies. Third, the activities carried out are analyzing data, presenting data, and making conclusions at this stage. Fourth, make research reports and make articles.

The research subjects consisted of school principals, five teachers, one school operator, and 75 children with 15 children in group $A 1,16$ students in A2. B1 group 15 people, B2 group 13 people, and B3 group 12 people. The total number of active children in the 2018/2019 school year was 71 children. Data collection techniques used are using observation sheets, interview questions, and documentation studies. The research data were analyzed using the theory of Miles and Huberman namely data reduction, data presentation, and verification or conclusions (Miles and Huberman, 1989: 21).

\section{RESULTS}

In Early Childhood Education, genderresponsive learning is an effort to break the cultural link that is gender-biased early on. According to Wibowo (2017: 25), gender-responsive learning is a learning process that provides balanced attention to the unique needs of men and women. Genderresponsive learning requires educators to pay attention to various learning approaches that meet gender equality and justice principles.

The following will describe the research results related to implementing gender-responsive learning in Bhayangkari Kindergarten of Ruteng.

\section{Overview of Learning that Fulfills the Rules of Gender Equality and Justice in Bhayangkari Kindergarten}

There are four (4) indicators related to the concept of learning that meets the rules of equality and gender justice. Among them are (a) learning planning, (b) teaching and learning interactions, (c) classroom management, (d) evaluation of learning outcomes. These four things are as described below:

\section{Learning Planning}

In planning learning, the things done by Bhayangkari Kindergarten of Ruteng are setting gender-responsive learning goals, paying attention to children's interest in developing learning tools, involving all children to participate actively without differentiating the gender, abilities, and culture of children

\section{Interaction of Teaching and Learning}

There are three things related to teaching and learning interactions, including the teacher's first behavior.

Children's behavior toward teachers is accustomed to being kind and polite. The thing done by children in Bhanyangkari Kindergarten is by giving and answering greetings when children come and go home from school, practice speaking with polite intonation. An exciting thing to do in this kindergarten is that before entering the core activities in learning, the teacher allows children to tell their daily experiences to their friends and teachers. The child who tells the story is asked to stand in front of the class while the other children are allowed to ask questions or talk about the story told by their friends. According to the teacher, the approach used is to instill the values of character so that children are trained to speak, build self-confidence, and respect fellow peers by paying attention to intonation when telling stories or asking questions. Also, the teacher allows children to tidy up the tools and play materials on the shelves or places that have been provided by the school, and the children are trained to ask permission to go to the bathroom or leave the classroom

Second, behavior towards fellow friends. Here students are taught and trained to behave positively towards their peers by providing guidance and direction and examples easily understood by children. Examples of activities carried out by schools are sharing food and drinks, playing together, thanking them when they receive something from a friend or teacher or when a friend finishes telling a class or when a friend asks a question, a friend tells a story to thank a friend who asks. This is accustomed to starting from group A children (4-5 years old) to group B children (Ages 5-6 years), forgiving each other if they make mistakes, respecting friends' 
Adriani Tamo Ina Talu. Elisabeth Sarinastitin/ Implementation of Gender Responsive Learning in Bhayangkari Kindergarten of Ruteng

property and not discriminating between male and female friends, friends Catholic, Protestant, Hindu and Muslim friends

\section{Class Management}

Class management includes spatial planning and organizing students by the needs, and planned programs will help achieve optimal learning. Class management in Early Childhood Education institutions must be adapted to the learning model used. Bhayangkari Kindergarten Institute uses a group learning model with safety activities in learning. Some things are done by Bhayangkari Kindergarten related to classroom management.

\section{a. Room Arrangement, Equipment, and Play}

Materials

Bhayangkari Kindergarten does some things in managing the space, tools, and play materials. Among them are first, the arrangement of furniture in the room adjusted to the activities carried out. Second, the grouping of children's tables and chairs are adjusted to the needs to free the child's space. The composition of the chair table can change. This only happens in class/group $B$, but in class or group $A$, the room is relatively narrow, so the child is not free to move. Third, walls can be used to attach facilities used as learning resources and children's activities. At Bhayangkari Kindergarten, walls are only used to attach the facilities used as learning resources and not the results of children's activities. Fourth, the arrangement and storage of tools and play materials are arranged so that they can train children for habituation to be achieved such as independence, responsibility, making decisions, habit of rearranging equipment, and so on. Fifth, play equipment for safety activities is arranged in the room to function if needed by children.

b. Learning Steps

b.1 Preliminary Activities

Preliminary activities carried out classically mean the activities carried out by all children in one class, in one unit of time with the same activity and heating nature. For example, discussing and asking questions about themes and sub-themes or experiences experienced by children (children are asked to talk about themes or sub-themes that will be learned that day). If there is boredom at the time of discussion, teachers are expected to make variations of activities such as physical/motor activities or games that train children's hearing.

b. 2 Core Activities

The nature of this activity is to activate the attention, abilities, and social emotions of children. Based on the results of observations and interviews, the activities carried out vary consisting of play activities that are selected and liked by children in order to be able to explore, experiment, increase understanding, concentration, bring initiative, independence and creativity and can help and develop good work habits both individuals and groups.

When the core activity, children are divided into several small groups. The division of groups pays attention to the abilities, gender, and religion of children. Before the children are divided into small groups, the teacher explains the activities or things related to each group's tasks classically. Teachers with children can give the name of each group. On this occasion, children are given the freedom to choose the activities in the group of interest and the place provided. All children take turns following the activities planned by the teacher. After the child can participate in an orderly fashion, they may choose their activities in an orderly manner. Children who complete their assignments faster than other friends can continue activities in other groups as long as they do not disturb other friends or are offered by the teacher to play in the safety group. There are also various tools and materials for play in the safety group that children did not do in some previous groups.

\section{b.3 Break/Eat}

This activity can sometimes be used to fill in the indicators/ abilities to be achieved 
relating to eating activities, for example, eating order, type of nutritious food, social taste, and cooperation. After the eating activity is finished, the remaining time can be used to play with the instruments provided outside the classroom to develop the child's physical/ gross motor skills.

\section{b.4 Closing}

The activities carried out in the closing activities are calming and given classically. What the Bhayangkari kindergarten teacher did before the activity was singing. This activity ends with questions and answers about the activities that take place to interpret the activities carried out.

\section{Evaluate Learning Outcomes}

While teaching and learning activities take place, the teacher should record everything that happens both to the program activities and students' development. From the results of observations made, teachers tend to assess children's development from work done by children and do not have special instruments in assessing the learning process of children.

\section{Gender Responsive Indicator}

Bhayangkari Kindergarten has developed several indicators of responsive learning in Early Childhood Education from the learning approach taken. Among them are providing opportunities for women and men to gain access to the same active participation in learning, obtain the same rights and obligations in the learning process, obtain the same services, and obtain the same learning/teaching materials.

Bhayangkari Kindergarten of Ruteng Institute has developed gender-responsive learning by the nature of gender-responsive learning even though there are still some facilities and infrastructures for children's play that are not gender-responsive.

\section{Learning Development Based on Children groups and Interests}

In developing gender-responsive learning in Bhayangkari Kindergarten, schools pay attention to children's grouping when playing and learning. The group formed considers the diversity of children in terms of abilities, culture and religion. In addition, in learning, teachers provide opportunities for children to learn based on children's interests so that children are given the freedom to choose games according to their interests.

\section{CONCLUSION}

Based on the overall presentation and analysis of the implementation of gender-responsive learning in Bhayangkari Kindergarten, the researcher can conclude the following:

First, the learning process carried out at Bhayangkari Kindergarten has fulfilled the principles of gender equality and justice seen from the learning planning process, teaching-learning interactions, classroom management, and learning evaluation. However, the choice of tools and play materials made by children while learning is still influenced by society's stereotypes about the boxing of tools and play materials made by women and men.

Second, Bhayangkari Kindergarten has developed a learning process based on genderresponsive learning indicators in early childhood, namely by giving equal opportunities to women and men to gain access and active participation in learning, obtain the same rights and obligations in the learning process, obtain services that are the same and get the same teaching material.

Third, to develop gender-responsive learning in Bhayangkari Kindergarten, schools pay attention to children's grouping when playing and learning. The group formed considers the diversity of children in terms of abilities, culture, and religion. Also, in learning, teachers provide opportunities for children to learn based on children's interests so that children are given the freedom to choose games according to their interests.

\section{REFERENCES}

Azisah, Siti. 2016. Buku Saku Kontekstualisasi Gender Islam dan Budaya. Makasar: UIN Alauddin.

Dina, Hermina. 2014. Strategi pelaksanaan Pengarustamaan Gender dalam Pendidikan 
Golden Age: Journal of Early Childhood Education, Volume 4 Nomor 01 (Juni 2020)

ISSN 2549-8371 | E-ISSN 2580-5843

Adriani Tamo Ina Talu. Elisabeth Sarinastitin/ Implementation of Gender Responsive Learning in Bhayangkari Kindergarten of Ruteng

dalam Jurnal Studi Gender dan Anak Vol II No 1 Januari-Juni 2014.

Instruksi Presiden No 9 Tahun 2000

Ikhwan, Kurniawan. 2014. Pembelajaran Responsif Gender pada Anak Usia Dini Menggunakan Media Berbasis ICT.

Ibrohim. 2018. Pembelajaran Responsif Gender pada PAUD

Petunjuk Pelaksanaan, Perencanaan dan Penganggaran yang Responsif Gender untuk Pemerintah Daerah. 2012.
Slavin, Robert F. 2009. Cooperative Learning: Teori, Riset, dan Praktik, terjemahan Nurulita. Bandung: Nusa Media.

Shlomo Saran. The Handbook of Cooperative Learning. Yogyakarta: Familia Grup Relasi Inti Media.

Trianto. Model-model Pembelajaran Inovatif Berorientasi Konstruktivistik. Jakarta: Prestasi Pustaka
Publisher, 